\title{
Foreign Institutional Investments and Liquidity of Stock Markets: Evidence from India
}

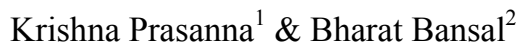 \\ ${ }^{1}$ Department of Management Studies, Indian Institute of Technology, Madras, Chennai, India \\ ${ }^{2}$ Indian Institute of Technology, Madras, Chennai, India \\ Correspondence: Krishna Prasanna, Department of Management Studies, Indian Institute of Technology, Madras, \\ Chennai, 600036, India. Tel: 91-44-2257-4571. E-mail: pkp@iitm.ac.in
}

Received: February 27, 2014

Accepted: April 1, 2014

Online Published: May 25, 2014

doi:10.5539/ijef.v6n6p103

URL: http://dx.doi.org/10.5539/ijef.v6n6p103

\begin{abstract}
Indian economy has experienced rapid economic growth rate and higher foreign institutional investment (FII) inflows over the decade 2001-2010.This paper examines the impact of Foreign Institutional Investments upon Indian stock market liquidity. Foreign institutional investments contributed for the growth of stock market activity in India. FII flows had significant positive impact on Market capitalisation, volume and value traded in the Indian market. However the empirical results indicate that Foreign Institutional Trading significantly influences market liquidity in a negative direction. Foreign Investments were found to granger cause market liquidity. A $1 \%$ change in the gross purchases in the current week will result in $0.10 \%$ decrease in the liquidity of the following week, whereas a $1 \%$ change in sales would result in $0.12 \%$ similar change. Results support the argument that across the emerging markets FIIs result in excess market volatility and lower liquidity.
\end{abstract}

Keywords: foreign institutional investments, gross purchases, gross sales, stock market liquidity

\section{Introduction}

Stock market liquidity is an important parameter to measure market growth and efficiency. Large markets that are liquid and efficient can continue to receive and sustain the required foreign investments to fund their economic growth. The relation between foreign portfolio flows (referred as Foreign Institutional Investments (FII) in this paper as it is the nomenclature in the Indian market) and their impact on the domestic markets has recently received increased attention in international asset pricing literature.

Recent research is focused on analyzing the impact of international flows on the equity market returns, cost of capital and volatility. Few studies observed a negative impact and reported that foreign flows result in excess market volatility; others have observed a positive impact and noted that FII flows reduce cost of capital. Trading by foreign investors leads to excess volatility, and potentially has a destabilizing effect (De Long et al., 1990). Bekaert and Harvey (2000), and Henry (2000) conducted empirical studies on liberalization in emerging markets and found that the cost of capital is reduced when markets opened up to foreign investors. However, while research on the impact of foreign flows on domestic market liquidity is still limited, market microstructure literature includes many studies on the liquidity patterns of emerging markets. This paper carries forward the research on foreign investment flows and liquidity of emerging markets to analyze the impact of FIIs on the liquidity of Indian Stock Markets.

Ree and Wang (2009) studied the Jakarta stock exchange in Indonesia and found that foreign institutional ownership had a significant negative impact on the future liquidity of markets. However, it must be noted that they used monthly foreign institutions' ownership data for their study. In India, there are many companies owned by foreign groups as well as subsidiaries of foreign companies in which foreign institutions continue to own large share holdings, and this does not affect the market liquidity or volatility. Hence, this paper uses the dataset of daily FII flows and stock index (C\&X Nifty) returns in India, to investigate the patterns and impact of foreign investors' purchases and sales on the liquidity of Indian Stock Market.

The study period of 2002-2009 saw both foreign Institutional investments and Indian stock market growing significantly. This paper explores the cause and effect relationship between the two. Further, since the growth of both FIIs as well stock markets is expected to improve market liquidity, this study examines whether the increase 
in FII flows in particular has any impact on the liquidity of Indian markets.

Stock market liquidity is measured through the Amihud illiquidity ratio to assess the price impact in the market. Turnover ratio and high low spread estimator (Shane \& Paul, 2011) were computed to examine the transaction cost and bid-ask spread in the market. Weekly average Foreign Institutional Investments (FII) were considered to estimate the impact of FII flows on the stock market. Weekly average trading flows were computed from daily gross purchases, sales and net investments. It is found that foreign trading (both purchases and sales) significantly improved trading activity in India. FII flows had a significant positive impact on the volume and value traded on the Indian Stock Market. Gross purchases and sales not only impacted market liquidity negatively, but were also found to have a negative lead effect on future liquidity.

\subsection{Growth of Indian Economy and Raising Foreign Institutional Investment (FII) Flows}

Indian economy has experienced a rapid economic growth rate and higher FII inflows over the decade 20012010.The economy is the ninth largest in the world by nominal GDP and fourth largest by the purchasing power parity (in 2010) (Note 1). Since liberalization in 1991 India's GDP (in rupees) has grown at about 8\%.

India opened its stock market to foreign investors in September 1992 and has since witnessed a steep growth in foreign participation through portfolio and direct investments. The net FII in 2010 was Rs. 357,597 crores (\$ USD 79228 Million) (Note 2). The Securities and Exchange Board of India (SEBI) has been liberal in maintaining a friendly regulatory framework to encourage FIIs. The restrictions on foreign investors to invest in the equity market have been progressively relaxed over time, and they have invested a sum of $\$ 3.09$ billion in the period of January-June 2011, out of which $\$ 85$ million was in equities. With a market capitalization of about $11 \%$ (as in 2010, Note 3), the foreign investors hold a great potential to influence the Indian equity market. The 9/11 attacks saw a decline in the FIIs, but the flows reverted to normal in a month's time. However, apprehension regarding the volatility of these investments has been of great concern to the emerging market economies (EME's) such as India. The global financial crisis and the consequent events have affected the portfolio flows into the country, but the recovery has been quick. The financial year 2008-2009 saw foreign investors withdrawing Rs. 660,386 Crores (\$ USD 141805 Million)from the Indian equity market. The foreign institutional investors have been blamed for the black Monday when the Sensex fell by more than 2000 points in a single day. While it is evident that FIIs has seen tremendous growth in the past two decades; the highly volatile investment nature of FII's is also distinctly visible. The foreign institutional investors saw tremendous returns in the first half of last decade, but, the reversal in market performance led to a decline in returns.The speculative and opportunistic nature of these investors led them to withdraw huge amounts of money from the country, which had a crippling effect on the economy on both a macro and microeconomic scale.

Since 1997 Asian crisis and the Tequila crisis in Mexico, the stability of these cross-border flows has been a topic of constant debate both amongst academicians and policymakers. It is imperative for an emerging market like India to thoroughly assess the pros and cons of the flow of foreign funds as it can have significant impact on firm level growth and economic growth of the country. This paper examines the impact of FIIs upon the liquidity of the Indian Stock Market.

\section{Literature Review}

\subsection{Impact of FIIs on the Stock Markets}

Theoretical literature has associated liquidity crisis with the exit of foreign investors and drop in foreign investments from the crisis economy. However, Mark and Geeta (2005) argued that liquidity crisis is equally consistent with an inflow of foreign capital in the form of mergers and acquisitions (M\&A). They noted that liquidity plays a significant and sizable role in explaining both the increase in foreign acquisitions and the decline in the price of acquisitions during the crisis.

The 1997 Asian financial crisis raised many questions about the behavioural impact of international investment flows on the stock market and emerging economies. Choe et al., (1999) from Korea observed that foreign investor trading did not destabilize their markets during the crisis. Froot et al.,(2001) used daily international portfolio flow data during 1994-1998 and found that the international flows succeed in timing foreign market investments especially in emerging markets. These flows also facilitate prediction of equity returns.

Dahlquist and Robertsson (2002) studied the investment behaviour of foreign investors in association with equity market liberalization in the Swedish equity market and found a strong link between foreigners' trading and local market returns. They noted that in the period following the liberalization, foreigners' net purchases led to a permanent increase in prices, or equivalently, a permanent reduction of the cost of equity capital. Grinblatt and Keloharju (2000) found that foreign investors tend to be momentum investors, buying past winning stocks and 
selling past losers.

Stulz (1999) showed that globalization allows "better" investors to participate in the market and improve corporate governance, thereby allowing for an improved relationship between the investors and managers. Foreign investors can address the issue of agency costs and the manager-investor asymmetry problem (Stulz, 1990 ), which is particularly acute in poorly managed firms in many emerging economies.

Wang (2004) noted a significant relationship between foreign equity trading and market volatility in Indonesia and Thailand. Even before the Asian crisis, he found that foreign trading, especially foreign selling, was the most significant source of market volatility. He reported that contrary to the expected outflows of portfolio investments during the Asian crisis, foreign investors were net buyers in both markets, and that foreign investors appeared to be leading in the price adjustment process in Indonesia.

Miguel and Pedro (2006) said that a key element in modern capital markets is the interplay between firms who raise capital internationally, and institutional investors who manage growing pools of assets. They found that all institutional investors reveal a strong preference for large and liquid stocks.

De La Torre et al. (2007) reported that the opening up of the markets can pose significant threats to policymakers and the migration of trade to an international platform can lead to reduced liquidity. Ree and Wang (2009) reported a negative impact of foreign institutional ownership on the markets future liquidity in Indonesia. They however stated that the market liquidity in the country rose despite an increase in FII, and indicated that this is due to the presence of various micro and macroeconomic factors that have the potential to dictate the market liquidity.

Using the 2003 US Dividend tax cut as a natural experiment, Chisen Wei (2010) observed that FIIs lead to an improved liquidity in the domestic markets. Bortolotti et al. (2007) covering 19 developed economies during 1985-2002 period, found that share issue privatization positively affects stock market liquidity. Mitra (2011) reported that foreign capital inflows into emerging markets have increased steadily in the past few years. He analyzed the determinants of foreign investor participation in local bond markets and concluded that foreign participation is influenced by (i) return prospects (ii) market liquidity and (iii) size of the market.

Chakrabarti (2001), Paramita Mukherjee et al. (2002) and Tanupa Chakraborty (2007) examined the FII flows in the Indian equity market. They concluded that flows are correlated to the returns and are more likely to be the effect than the cause of the market returns. Chakrabarti (2001) also showed that the flows are negatively related to beta of the Indian stock market; but has noticed the change in this relationship after the Asian crisis. This demonstrates that blaming the foreign investors for plunge in stock returns may be irrational.

\subsection{Liquidity Patterns in Emerging Markets}

Liquidity is an important attribute of an efficient stock market. Stock market liquidity is a robust predictor of economic growth and capital accumulation (Bernardo, 2002). Liquid markets encourage and engage financial analysts to provide price forecasts and facilitate efficient price formation in markets. Liquidity also predicts future returns and liquidity shocks are positively correlated with return shocks (Amihud, 2002; Jones, 2002). Emerging markets are characterized by volatile, but substantial returns that can easily exceed $75 \%$ per annum. Balancing these lofty returns are the liquidity concerns of trading in emerging markets (Lesmond, 2002). Chordia, Roll, and Subrahmanyam (2000) studied the US market and concluded that liquidity is not an asset specific attribute; rather, individual asset liquidity tends to be positively co-related to aggregate market liquidity.

A market is liquid if the cost of buying or selling a large number of shares on demand is low. This suggests that the costs of acquiring capital are lower in more liquid markets. Thus, liquidity in the stock market has consequences for a firm's financing/investment policies. There are a number of factors that can impact stock market liquidity. Glosten and Milgrom (1985) argued that one cause of illiquidity is the presence of privately informed traders. Academicians frequently assert that institutional investors play an important monitoring role, and also that there exists a relation between institutional ownership in a firm and the liquidity of the firm's stock (cf. Wahal, 1996). The influence of institutional investors on stock liquidity is further reinforced by the influence of their trading practices on stock price (Lakonishok et al., 1992). Agarwal (2007) examined the relationship between institutional ownership and liquidity of stocks, focusing on the effect of the institutions' information advantage on liquidity. He found evidence of a non-monotonic (U-shaped) relationship between the fractions of a firm's shares held by institutions and various measures of stock liquidity, and showed that liquidity rises with increased institutional ownership but declines once it crosses a $70 \%$ mark. He also observed that institutional ownership (Granger) causes liquidity. Bekaert et al. (2007) demonstrated that the level of openness of a country can have a positive influence on the market's liquidity. 


\section{Data and Methodology}

\subsection{Data Source and Time Period}

CNX Nifty Index of National Stock Exchange (NSE) has been taken as proxy for the Indian Stock Market to investigate the relation between FIIs and the Indian Stock Market. The calendar years 2002-2009 have been taken as the study period covering 423 weeks of trading activity.

The daily stock market data was collected from the NSE website as well as from CMIE Prowess, data base of Centre for Monitoring Indian Economy (CMIE). The data regarding daily foreign institutional investment flows has been collected from the SEBI website.

\subsection{Foreign Institutional Investment: Selection of Proxies}

Kamesaka et al. (2003) analyzed weekly investment flows in the Tokyo Stock Exchange (TSE) during 19801997 using aggregate buying and selling amounts from foreign investors. Dahlquist and Robertsson (2002) analyzed monthly gross purchases and sales of shares made by foreigner investors in 322 listed firms in Sweden. They measured net purchases as the difference between purchases and sales while purchases plus sales are referred to as trading.

This research uses daily data of gross purchases and sales of shares made by foreign investors in the Indian market. Net Investment (NI) is the daily difference between purchases and sales. This daily data is used to compute weekly average gross purchases, sales and net FII flows. Net FII flows indicate whether foreign investors were net buyers or sellers during week. Large net buying/selling signals what the investor group thinks about the Indian stocks, whether they are under/overvalued, with regard to the alternative markets.

The impact of FII flows has been analysed from the alternative related variables to generalise the observations. Gross purchases directly result in demand while gross sales provide additional supply of stocks in the market; and net investment indicates the net purchases. These variables on any trading day may not only influence the liquidity of the same day but may also influence trading sentiment and future liquidity and thus have a lead effect. Hence, the change in these variables and log change have also been considered as independent variables in the analysis.

\subsection{Selection of Liquidity Proxies}

As mentioned in the review section, there are various measures of liquidity that have been used in recent literature. Heflin and Shaw (2000) and Sarin et al. (2000) used the traditional liquidity measures and reported larger spreads and smaller quoted depths due to larger institutional ownership. Rubin (2007) reported that the impact was similar on the NYSE. Shane and Paul (2011) developed a bid-ask spread estimator based on daily high-low prices. This estimator also captures the stocks' variance in returns and is expected to outperform the usual low frequency estimators. This measure was found to be an important and relevant transaction-cost based measure in the Indian scenario where the availability of the traditional measures such as the bid-ask spread and market depth is difficult due to the order driven nature of the market structure. The alternatives normally used in order driven markets include the turnover based measures. The rupee turnover, volume traded (number of shares traded), and Log of Turnover have been considered as alternative market liquidity proxies. Amihud illiquidity ratio and turnover ratio are also used to measure liquidity. Higher illiquidity ratio indicates lower liquidity of the market and vice versa. Apart from these ratios, the Shane (2011) spread estimator has also been computed and included as liquidity proxy in the analysis. These ratios were taken as dependent variables reflecting the Indian Stock Market liquidity in the analysis.

\subsubsection{Trading Volume}

Higher trading volume indicates higher liquidity in the market. Brennan et al. (1998) used trading volume to measure liquidity. Bailey and Jagtiani (1994), Amihud, Mendelson, Lauterbach(1997), and Berkman and Eleswarapu (1998) used trading volume as a liquidity proxy for price impact to explain return differentials in studies on the Thai, Israeli, and Indian Stock Exchanges, respectively. In this study daily trading volume represented by the number of shares traded on CNX Nifty stock index was considered to compute weekly average, which has been used as one of the proxies for stock market liquidity.

\subsubsection{Turnover}

Turnover indicates the level of trading activity in the market. Empirical research studies prescribed close association between turnover and bid-ask spread. Levine and Schmukler (2005) and Datar et al. (1998) used turnover as proxy for stock liquidity. Dahlquist and Robertsson (2001) used turnover as a liquidity proxy in tests of association between foreign ownership and the market liquidity of a firm's shares. The present study uses 
rupee turnover and its log value as alternative proxies for liquidity. Higher turnover signals higher market liquidity. However, turnover does not measure price impact and is not a precise measure of liquidity. Hence, other measures of liquidity have also been computed to analyse the impact of FII flows on Indian Stock Markets.

\subsubsection{Turnover Ratio}

Turnover ratio has been widely adopted as the proxy for market liquidity by previous cross-country empirical studies (Levine, 1997; Bernardo, 2002). Considering the trading value to the country's GDP and the trading value to the market capitalization (turnover ratio) as liquidity proxies, Levine et al. (1998) and Bekaert et al. (2007) observed that the liberalization process increased the overall liquidity in emerging economies.

Turnover ratio was computed by taking the daily total value of shares traded scaled by total daily market capitalization; this was averaged over the period of the total working days in the week. The turnover ratio is a measure of liquidity as well as of transaction costs. High turnover ratio indicates low transaction costs and is related to the size of the market; a small, liquid market will have a high turnover ratio. Liquidity is an important attribute of stock markets because, in theory, liquid markets improve the allocation of capital and enhance prospects for long-term economic growth.

Lesmond (2005) indicated that the trading value-based measures do not capture the cross-sectional differences in the cost per trade across stocks. They tend to increase during volatile periods when liquidity may actually be driven down. Hence the Amihud illiquidity ratio is computed to measure the price impact.

\subsubsection{Illiquidity Ratio}

Amihud (2002) demonstrated illiquidity ratio and suggested that it can be used to measure the price impact. Stock market illiquidity is defined as the average ratio of the daily absolute returns to the (rupee) trading volume of the day. It is the ratio of the return per day to the daily traded volume in rupees. This value is then averaged across the number of trading days in a week to get the proxy for market liquidity. Amihud (2002) noted that this ratio is closely related to the Amivest ratio and also follows Kyle's (1985) concept of illiquidity, which is the response of price to order flow. Marcelo and Quiros (2006) commented that the illiquidity ratio has a strong theoretical appeal and considers it as the best proxy for illiquidity. Bortolotti et al. 2007 computed the Amihud ratio for stock index for measuring the liquidity of US stock markets and noted that the computed values are closely correlated to the average of the individual stock price-impact measures. Following the same approach this paper computed the Amihud illiquidity index from the daily market data of CNX Nifty Index of NSE.

$$
\text { Daily log returns: } R=\log \left(P_{1} / P_{0}\right)
$$

where $\mathrm{R}$ is the daily $\log$ return, $\mathrm{P}_{1}$ is the current day's closing price and $\mathrm{P}_{0}$ is the previous day's closing price. The absolute values of these returns were taken to compute the following Illiquidity Ratio.

$$
I L L I Q_{d w}=\frac{1}{D_{w d} \Sigma_{t=1}^{D_{d, w}} \frac{\left|R_{d, w}\right|}{\operatorname{VOLD} D_{d, w}}}
$$

where $\mathrm{R}_{\mathrm{d}, \mathrm{w}}$ is the return on day $\mathrm{d}$ of week and $\operatorname{VOLD}_{\mathrm{d}, \mathrm{w}}$ is the respective daily volume in rupees (Amihud, 2002). This value was then multiplied by $10^{2}$ and reported in percentage terms. This was then averaged over the period of working days in the week. A high value of this measure indicates that the market is illiquid because there is a considerable price change in the stock in response to a comparatively small change in the turnover.

\subsubsection{Spread}

Apart from these proxies, the Shane and Paul (2011) spread estimator has also been computed and included as a liquidity proxy in the analysis. The method relies on the fact that the high, low price ratio reflects two things, the true variance in the stock prices (which grows proportionally over time) and the bid-ask spread. The model is based on the assumption that high prices represent buyer initiated trade and can be taken as proxy for buy-quotes and low prices are seller initiated trade and represent sell-quotes. Shane and Paul (2011) derived a spread estimator as a function of high-low ratios over one-day and two-day intervals. The model is developed on the argument that the sum of the price ranges over two consecutive single days reflects two days' volatility and twice the spread, while the price range over a one two-day period reflects two days' volatility and one spread. Their simulations revealed that the correlation between high-low spread estimates and true spreads is about 0.9 and therefore this spread estimator provides a good alternative liquidity proxy for order driven markets.

The assumption of small-spreads was found to hold true for the NSE stocks in India and hence a closed solution is used for the analysis where spread is: 


$$
\text { Spread } S=\frac{2\left(e^{\infty}-1\right)}{\left(1+e^{\infty}\right)}
$$

Where $\alpha$ is computed from the following

$$
\text { Alpha } \alpha=\frac{\sqrt{2 \beta}-\sqrt{\beta}}{3-2 \sqrt{2}}-\sqrt{\frac{\gamma}{3-2 \sqrt{2}}}
$$

In which beta is computed using

$$
\operatorname{Beta} \beta=\left\{\sum_{j=0}^{l}\left[\ln \frac{H_{t+j}^{0}{ }^{0}}{L_{t+j}^{0}}\right]\right\}
$$

where $\mathrm{H}^{0}$ and $\mathrm{L}^{0}$ are the observed high and low on two consecutive time periods and gamma represents

$$
\text { Gamma } \gamma=\left[\ln \frac{H_{t, t+1}^{0}}{L_{t, t+1}^{0}}\right]^{2}
$$

where the high and low values are the higher and lower of the observed highs and lows over the two time periods.

Adjustment for over-night price changes: The estimator has an implicit assumption of stock values remaining unchanged when the market is closed. To make the analysis robust, the method suggested by Shane and Paul (2011) has been used to account for these changes. This becomes important as a two-day rolling period was used in the formulation. If the low of day $t+1$ (today) was above the close price of day $t$ (yesterday), the high and low of $t+1$ day are reduced by the amount of over-night changes. A similar approach was taken in case the $t+1$ high was below the day $t$ close. However, it should be noted that the assumption of continuous trading (daily) is not valid strictly due to many non-trading days.High-low spread was computed for each of the 50 stocks included in the CNX Nifty Index for each day. The average of all the 50 stocks has been taken as spread for that trading day. While computing this average, if the spread of the individual stock was found to be negative, it was set to be zero (Shane and Paul, 2011). This computed daily spread was used to calculate weekly average spread in the Indian market.

\section{Results and Findings}

\subsection{FII Flows and the Indian Stock Market: Data Patterns}

The yearly averages of Gross Purchases, Gross Sales, Net Investment, CNX Nifty Index Turnover, P/E (Price earnings ratio) and the index returns for the period of 2002-2009 are summarized in Table 1 and are presented in Figure1. The trading activity of the foreign investors has grown significantly in this period with Gross Purchases, Gross Sales and the Net Investment having a compounded annual growth rate of $39.2 \%, 37.9 \%$ and $50.6 \%$ respectively. The Index returns and Turn-over increased by $14.7 \%$ and $25 \%$ in the same period.

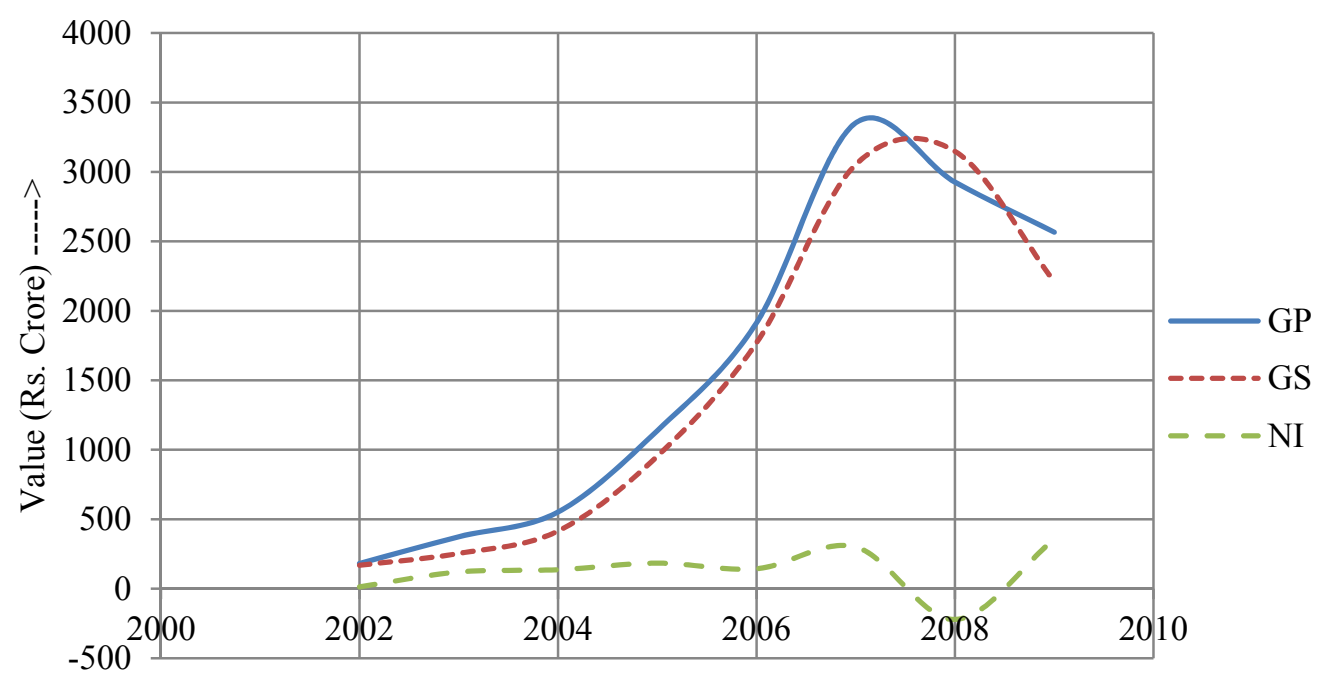

Figure 1. Foreign institutional investment flows in India during the period 2001-2010

Note. The values have been scaled so as to entail easier visualization. Actual values given in Table 1 .

GP : Gross Purchases, GS: Gross Sales, NI: Net Investment. 
Table 1. Foreign investment flows and Indian stock market performance during 2002-2009

\begin{tabular}{llllllllll}
\hline Year & $\mathbf{2 0 0 2}$ & $\mathbf{2 0 0 3}$ & $\mathbf{2 0 0 4}$ & $\mathbf{2 0 0 5}$ & $\mathbf{2 0 0 6}$ & $\mathbf{2 0 0 7}$ & $\mathbf{2 0 0 8}$ & $\mathbf{2 0 0 9}$ & CAGR (\%) \\
\hline Turnover (Rs. Cr) & 1447.65 & 2308.68 & 2760.04 & 2749.41 & 3997.28 & 5411.12 & 6997.76 & 8591.94 & 24.9 \\
P/E & 12.02 & 16.04 & 15.15 & 17.26 & 21.97 & 28.15 & 13.67 & 21.61 & 7.6 \\
PB & 1.99 & 3.29 & 3.12 & 3.74 & 4.41 & 5.22 & 30 & 3.22 & 6.2 \\
Returns & 0.22 & 0.75 & 1.23 & 0.54 & -0.02 & 0.88 & -0.76 & 0.66 & 14.7 \\
GP (Rs. Cr) & 182.04 & 374.07 & 551.87 & 1137.67 & 1913.45 & 3352.98 & 2926.48 & 2566.6 & 39.2 \\
GS (Rs. Cr) & 168.56 & 253.81 & 415.19 & 953.64 & 1769.69 & 3052.86 & 3147.98 & 2209.9 & 37.9 \\
NI (Rs. Cr) & 13.48 & 120.27 & 136.69 & 184.04 & 143.76 & 300.12 & -221.5 & 356.65 & 50.6 \\
No. of Shares Traded & 50470572 & 91956495 & 99263705 & 70421939 & 82141492 & 98239920 & $1.71 \mathrm{E}+08$ & $2.84 \mathrm{E}+08$ & 24.1 \\
Turnover ratio & 4.4 & 5.21 & 4.93 & 2.57 & 2.47 & 2.1 & 2.85 & 3.42 & -3.09 \\
Amihud Illiquidity (\%) & 1.935 & 1.898 & 2.159 & 3.572 & 4.656 & 5.368 & 7.35 & 4.247 & 10.3 \\
Spread in \% & 0.296 & 0.338 & 0.476 & 0.403 & 0.5 & 0.406 & 0.767 & 0.643 & 10.2 \\
M. Cap & 328.6 & 443 & 559.4 & 1068.3 & 1615.4 & 2568.7 & 2454.6 & 2508.1 & 29 \\
\hline
\end{tabular}

Note. *Data source: www.nseindia.com \& www.sebi.gov.in

Table headers are abbreviated as: GP, GS, NI: Gross purchases, Gross sales and Net Investment, P/E: Price earning multiple, PB: Price to book value ratio, MCap :Market capitalization.

Figure 2 depicts the trend in the liquidity proxies that have been used in the paper. It was observed that the Number of Shares traded and the Turnover grew significantly in the period 2002-2009 with a compounded annual growth rate of $24.1 \%$ and $25 \%$ respectively. This growth in volume and value traded indicates the growth in the trading activity of Indian markets. This should have resulted in higher turnover ratios and improved the liquidity. However, the turnover ratio fell over the years (Table 1 and Figure 2) and the Amihud Illiquidity raised by $10 \%$. Turnover rose, the turnover ratio (ratio of turnover to market capital) fell, as market capital increased at a much higher rate than the turnover (Figure 2). The trend in the bid-ask spread (HL estimator was used to estimate this in the Indian context) also rose by $10 \%$. The spreads were small and negative on some trading days as the CNX Nifty Index stocks were the sample companies for computing average spread on a trading day. These stocks represented highly liquid stocks in Indian market with lower bid ask spread. Weekly averages revealed that the spread fluctuated rapidly along the zero mark. These patterns signal that FII flows resulted in higher trading activity in volume and a value that was highly volatile. This argument is further reinforced by the higher growth in shares traded on the NSE in the volatile global financial crisis period of 2008-2009 when the spread rose to 7 .

Trends in Liquidity proxies

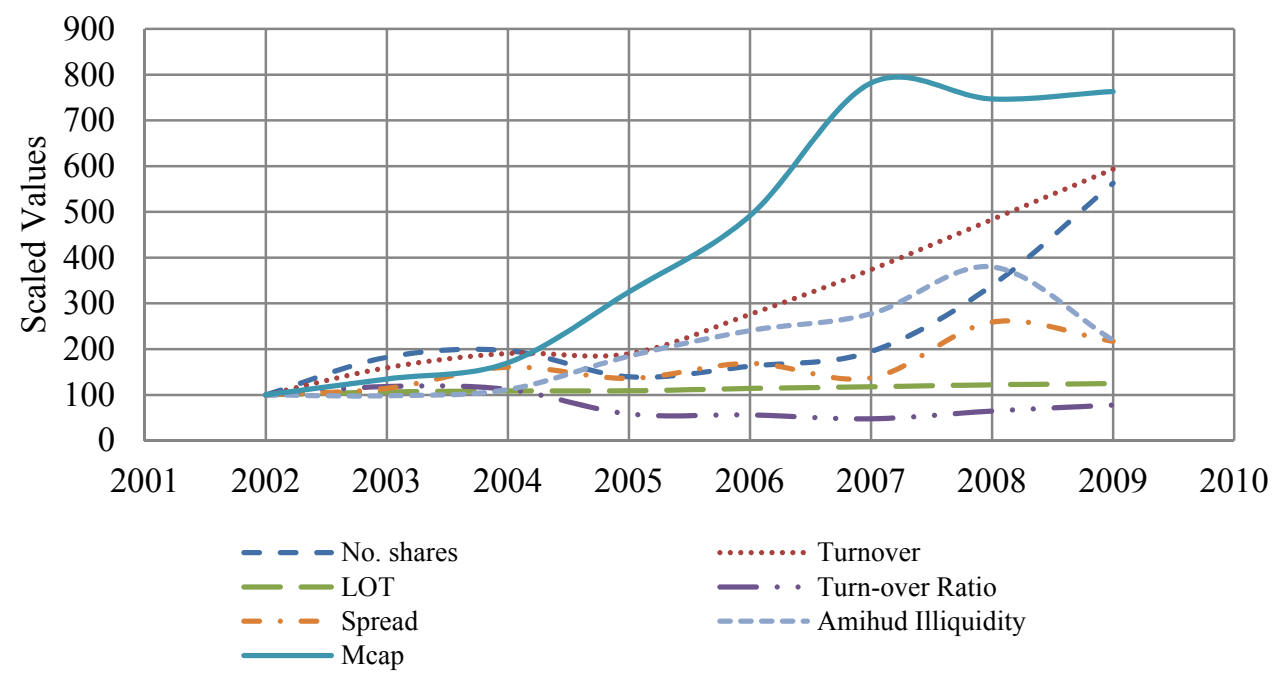

Figure 2. Liquidity trends in Indian stock market 


\subsection{Weekly Variables and Summary Statistics}

The summary statistics for the liquidity measures are presented in Table 2 . The values have been computed for a database of 422 weekly data points. The medians are comparable to the means indicating a low skewness in the data. The summary statistics for the FIIs are presented in Table 3.

Table 2. Weekly summary statistics-liquidity variables (2002-2009)

\begin{tabular}{|c|c|c|c|c|c|c|}
\hline & $\begin{array}{c}\text { No. of shares } \\
\text { traded (millions) }\end{array}$ & Turnover (Rs. Cr) & $\begin{array}{c}\text { Log } \\
\text { (Turnover) }\end{array}$ & $\begin{array}{c}\text { Turnover } \\
\text { Ratio }\end{array}$ & $\begin{array}{c}\text { Spread } \\
\text { (In \%) }\end{array}$ & $\begin{array}{c}\text { Amihud Illiquidity } \\
\text { (In \%) }\end{array}$ \\
\hline Mean & 118.67 & 4287.29 & 3.541 & 3.502 & 0.48 & 3.9 \\
\hline Median & 87.49 & 3395.56 & 3.526 & 3.244 & 0.39 & 3.077 \\
\hline Maximum & 482.81 & 16445.72 & 4.189 & 7.583 & 3.02 & 20.4 \\
\hline Minimum & 35.07 & 851.83 & 2.924 & 1.37 & 0 & 0.241 \\
\hline Std. Dev. & 82.31 & 2703.81 & 0.27 & 1.371 & 0.4 & 2.61 \\
\hline
\end{tabular}

Table 3. Weekly summary statistics-foreign institutional investments (2002-2009) (Note 4)

\begin{tabular}{llllllllll}
\hline & GP & CGP & LCGP & GS & CGS & LCGS & NI & CNI & LCNI \\
\hline Mean & 1626.1 & -1.9 & 0.6 & 1497.1 & 1 & 0 & 129 & -2.8 & 0 \\
Median & 1295.5 & -1.3 & 0.6 & 1140.8 & 1.4 & 0 & 94.1 & 0.9 & 0 \\
Maximum & 6991.8 & 2306.2 & 3.3 & 7787.4 & 2627.4 & 3.3 & 2356.5 & 645 & 2.3 \\
Minimum & 55.8 & -3519.1 & -3.5 & 67.7 & -3716 & -3.6 & -1977.8 & -808.1 & -2.4 \\
Std. Dev. & 1372.3 & 295.9 & 1.2 & 1344.7 & 311.9 & 0.8 & 430.7 & 148.8 & 0.7 \\
\hline
\end{tabular}

The daily spreads were averaged across each week to obtain the high-low estimate on a weekly frequency. Higher spread indicates lower liquidity and lower spread indicates higher liquidity. The H-L spread was found to be negative and very small in the Indian market taking CNX Nifty as the benchmark. The H-L estimator assumed both positive and negative values in the Indian context and were usually very low as depicted by the mean values. The negative values indicate that two-day variance of prices is more than twice as large as the single-day variance. This indicates significant volatility in the market due to large over-night price changes. It also signals that the total return volatility over the two-day period is higher as compared to the intra-day volatility.

Table 3summarizes the gross purchases and sales of foreign institutional investors in the Indian equity market. They sold on an average Rs.1497.1 crores of stock per week on the Indian Stock Markets during the sample period. The minimum sales week, valued at Rs. 55.8 crores, was the last week of 2002 when foreign trading started taking off on a big scale in India. The maximum sales value was Rs. 7787.4 crores and it was recorded in the $4^{\text {th }}$ week of January 2008 , in the global financial crisis period.Foreign investors made average weekly purchases of 1626.1 crores. The minimum and maximum purchases occurred during the first week of January 2003 and the $3^{\text {rd }}$ week of October 2007, respectively.

It is to be noted that standard deviations are very high for average daily change in Gross purchases (CGP) within a week and Change in Gross sales (CGS). This indicates that the occurrence of extreme values is highly probable which reinforces the idea of "volatility of foreign institutional investments".Figure 3 presents the frequency of Changes in Gross Sales of equity stock by foreign institutional investors over the past 8 years (2002-2009). The trend in Change in Gross Sales indicates that the negative changes in Gross Sales were 3.3 times higher compared to positive changes. It is clear that the $0-500$ Crore band accounts for $72 \%$ of the observations (total 422) indicate that the investments have been largely positive during this period. 


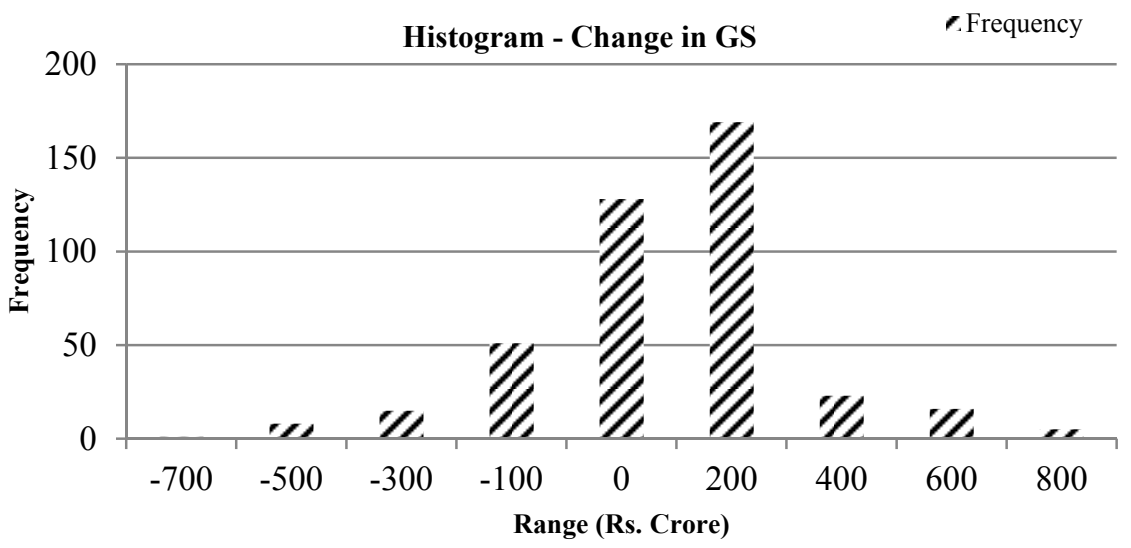

Figure 3. Changes in gross sales

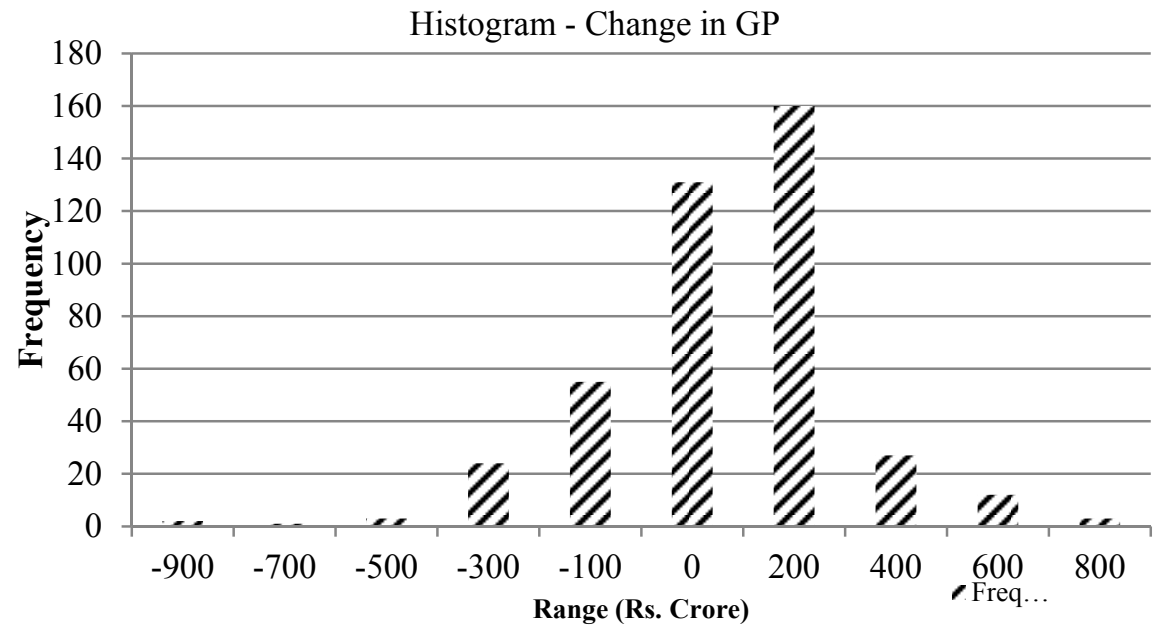

Figure 4. Changes in gross purchases

Note. Negative values indicate a investment outflows.

Change in Gross Purchases (Figure 4) indicates that investors had increased their purchases progressively over the 8 year period. Considering the central $400 \mathrm{Cr}$. band it was observed that the positive changes in Gross Purchases was 3 times higher compared to negative ones.

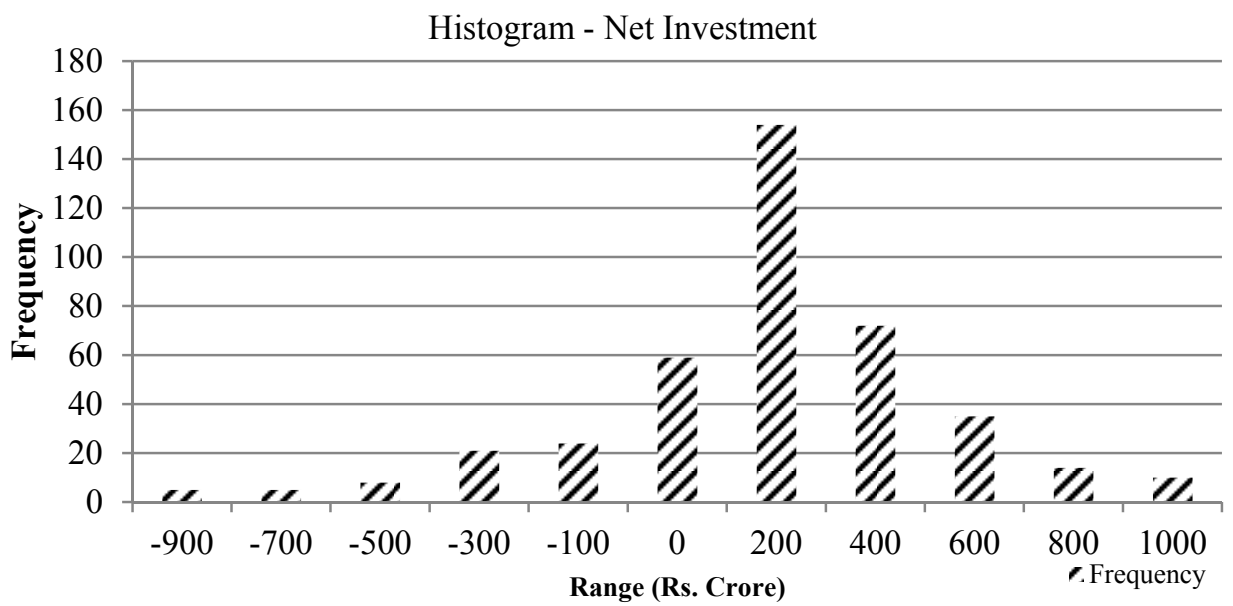

Figure 5. Changes in net investment 
Based on frequency graph of Changes in Net Investment it was concluded that the chances of the investments increasing on a weekly basis are roughly 1.7 times higher compared to them going down. On a yearly basis, after a peak of Rs. $300 \mathrm{Cr}$./weekin the year 2007, the net investments tumbled down to an almost negative Rs. 220 $\mathrm{Cr}$./weekin the next year. However, the market showed recovery with Net investments being Rs. $356 \mathrm{Cr}$. /week in the year 2009. It was observed that both the purchases as well as sales were very high in the market with average values close to Rs. $2000 \mathrm{Cr}$. /week in the period of 2006-2009 when the financial markets fell due to the global crisis. However, the net investments were only about Rs. $144 \mathrm{Cr}$. /week in the same period.This is a strong evidence of the volatile nature of the foreign institutional investments.

\subsection{The Impact of FII on the Market Liquidity}

\subsubsection{OLS Regression Estimates (Bi-Variate)}

Correlation coefficients of the Liquidity measures and FII flows were obtained to gauge the interrelationships between them. It is clear from the correlation statistics given in Table 4 that FIIs (both gross purchases and sales) are positively correlated with volume traded and turnover indicating higher flows are associated with higher trading activity in the market. FII flows have positive correlation with Amihud illiquidity and spread indicating lower market liquidity with higher purchases and sales from foreign institutional investors. Net FII is the value of daily excess purchases over sales. Higher NI indicates positive sentiment and is associated with higher liquidity in the market.

Table 4. Correlation between foreign institutional investments and stock market performance measures

\begin{tabular}{|c|c|c|c|c|c|c|c|c|c|}
\hline & $\begin{array}{c}\text { Gross } \\
\text { purchases }\end{array}$ & $\begin{array}{c}\text { Gross } \\
\text { sales }\end{array}$ & $\begin{array}{c}\text { Net } \\
\text { investment }\end{array}$ & $\begin{array}{l}\text { No. of } \\
\text { shares }\end{array}$ & Turnover & $\begin{array}{c}\text { Log of } \\
\text { Turnover }\end{array}$ & $\begin{array}{c}\text { Turnover } \\
\text { Ratio }\end{array}$ & Spread & $\begin{array}{l}\text { Amihud } \\
\text { Illiquidity }\end{array}$ \\
\hline Gross purchases & 1 & & & & & & & & \\
\hline Gross sales & 0.95 & 1 & & & & & & & \\
\hline Net investment & 0.22 & -0.1 & 1 & & & & & & \\
\hline No. of shares & 0.44 & 0.42 & 0.1 & 1 & & & & & \\
\hline Turnover & 0.82 & 0.8 & 0.12 & 0.83 & 1 & & & & \\
\hline Log of Turnover & 0.83 & 0.81 & 0.11 & 0.77 & 0.95 & 1 & & & \\
\hline Turnover Ratio & -0.49 & -0.48 & -0.05 & 0.13 & -0.18 & -0.26 & 1 & & \\
\hline Spread & 0.19 & 0.26 & -0.23 & 0.37 & 0.33 & 0.33 & 0.05 & 1 & \\
\hline Amihud Illiquidity & 0.51 & 0.63 & -0.33 & 0.25 & 0.43 & 0.5 & -0.42 & 0.45 & 1 \\
\hline
\end{tabular}

Table 5 presents the OLS estimates and impact of trading flows on all the liquidity proxies. Volume traded, turnover and log value of turnover represent trading activity proxies, while Amihud illiquidity ratio, spread and turnover ratio represent liquidity proxies. Gross purchases, sales and net investment have a statistically significant positive impact on trading activity proxies. FII flows have greater impact on turnover in comparison to the volume traded.

Table 5. Impact of foreign institutional investments on OLS regression estimations (without lags)

\begin{tabular}{lcccccc}
\hline & Liquidity Proxies & & & \multicolumn{2}{c}{ Trading activity Proxies } \\
\cline { 2 - 7 } & Amihud Illiquidity & Turnover Ratio & Spread & No. of shares & Log turnover & Turnover \\
\hline Gross Sales & $0.001225^{* * *}$ & $-0.00049^{* * *}$ & $7.89 \mathrm{E}-05^{* * *}$ & $24452.7^{* * *}$ & $0.000163^{* * *}$ & $1.60^{* * *}$ \\
t-statistic & -16.69 & $(-11.23)$ & -5.61 & -9.35 & -28.12 & -27.08 \\
R-square & 0.398 & 0.231 & 0.264 & 0.172 & 0.653 & 0.8 \\
Gross Purchases & $0.000978^{* * *}$ & $-0.00049^{* * *}$ & $5.44 \mathrm{E}-05^{* * *}$ & $26329.5 * * *$ & $0.000163^{* * *}$ & $1.61^{* * *}$ \\
t-statistic & -12.72 & $(-11.37)$ & -3.88 & -10.01 & -29.93 & -29.3 \\
R-square & 0.264 & 0.235 & 0.03 & 0.192 & 0.68 & 0.67 \\
Net Investment & $-0.00202 * * *$ & $-4.12 \mathrm{E}-05$ & $-2.2 \mathrm{E}-04^{* * *}$ & $19151^{* *}$ & $6.67 \mathrm{E}-05^{* *}$ & $0.761^{* *}$ \\
t-statistic & $(-7.26)$ & $(-0.93)$ & $(-4.89)$ & -2.06 & -2.17 & -2.5 \\
R-square & 0.334 & 0.04 & 0.232 & 0.1 & 0.105 & 0.121 \\
\hline
\end{tabular}

Note. $* *$ Significant at $99 \%, * *$ Significant at $95 \%, *$ Significant at $90 \%$.

Higher purchases and sales had a significant negative impact on the liquidity of the market. Both Amihud ratio 
and spread had positive coefficients indicating lower liquidity. Significant negative coefficient on turnover ratio also confirms the negative impact of FII flows on market liquidity. Net FII represents excess of purchases over sales and it was a positive amount in all the years except in the year 2008, when it had a negative relationship with liquidity proxies. Positive NI alone contributes to increased liquidity of the stock market.

\subsubsection{Granger Results}

Granger causality was tested to understand the cause and effect relationship between FIIs and market liquidity. The impact of FII on the liquidity of the Indian stock market was found to be significant up to 1 lag in the trading week. It was observed that Gross Sales and Gross Purchases cause strong but identical changes in the liquidity, Market Spread and the Turnover ratio.Table 6 presents F statistics indicating statistical significance.The impact of Gross Sales and Purchases as well as their changes is statistically significant at $99 \%$ confidence level. Table 6.1 summarises lead effect of FII flows upon the alternative liquidity proxies.

Table 6. F-statistics for the Granger test are summarized

\begin{tabular}{|c|c|c|c|c|c|}
\hline \multicolumn{6}{|c|}{ Null hypothesis : Foreign investment does not granger cause Liquidity(or illiquidity) in the market } \\
\hline & GS & CGS & GP & CGP & NI \\
\hline No. of shares & & $13.54 * * *$ & & $10.61 * * *$ & \\
\hline Log of Turnover & & $8.76^{* * *}$ & & $10.30 * * *$ & $12.48 * * *$ \\
\hline Turnover Ratio & $22.60 * * *$ & $4.62 *$ & $17.52 * * *$ & $5.76^{*}$ & \\
\hline Amihud Illiquidity & $25.75^{* * *}$ & & $36.91 * * *$ & & $4.42 *$ \\
\hline Spread & $13.85^{* * *}$ & $7.76^{* * *}$ & $12.52 * * *$ & $8.78 * * *$ & \\
\hline Turnover & & $13.37 * * *$ & & $15.64 * * *$ & \\
\hline
\end{tabular}

Table 6.1. Results of Granger test

\begin{tabular}{llllll}
\hline & GS & CGS & GP & CGP & NI \\
\hline Amihud Illiquidity & $\sqrt{ }$ & & $\sqrt{ }$ & & \\
No. of shares & & $\sqrt{ }$ & & $\sqrt{ }$ & \\
Log of Turnover & & $\sqrt{ }$ & & $\sqrt{ }$ & $\sqrt{ }$ \\
Turnover Ratio & $\sqrt{ }$ & $\sqrt{ }$ & $\sqrt{ }$ & $\sqrt{ }$ & \\
Spread & $\sqrt{ }$ & $\sqrt{ }$ & $\sqrt{ }$ & $\sqrt{ }$ & \\
Turnover & & $\sqrt{ }$ & & $\sqrt{ }$ & $\sqrt{ }$ \\
Score & 3 & 5 & 3 & 5 & 2 \\
\hline
\end{tabular}

\subsubsection{FII Flows: Lead Effect}

Based on the Granger test results, OLS regression coefficients have been estimated to quantify and assess the impact of FIIs on market liquidity. These estimations are made with the data aligned with lead effect.The independent variable at time $t$ has been regressed against dependent variables at time $t+1$. That is to infer that the FII flows of the week tend to influence the future liquidity in the following week. The summary of regression results across the alternative variables is presented in Table 7. The coefficients were estimated only for those variables for which the Granger results are significant.

Table 7. OLS regression with lead effect

\begin{tabular}{lccc}
\hline \multicolumn{4}{c}{ Liquidity Proxies } \\
& Amihud Illiquidity & Turnover Ratio & Spread \\
\hline Gross Sales & $0.001225^{* * *}$ & $-0.00053^{* * *}$ & $8.12 \mathrm{E}-05^{* * *}$ \\
t-statistic & -16.69 & $(-12.49)$ & -5.78 \\
R-square & 0.398 & 0.271 & 0.07 \\
Gross Purchases & $0.0010348^{* * *}$ & $-0.000513^{* * *}$ & $6.08 \mathrm{E}-05^{*}$ \\
t-statistic & -13.29 & $(-12.287)$ & -3.88 \\
R-square & 0.3 & 0.263 & 0.186 \\
\hline
\end{tabular}




\begin{tabular}{lccc}
\hline Net Investment & $-0.00137^{* * *}$ & $-4.12 \mathrm{E}-05$ & $-1.73 \mathrm{E}-04^{*}$ \\
t-statistic & $(-4.77)$ & $(-0.265)$ & $(-4.89)$ \\
R-square & 0.051 & -0.002 & 0.03 \\
\hline
\end{tabular}

Note. $* * *$ Significant at $99 \%, * *$ Significant at $95 \%, *$ Significant at $90 \%$.

Table 8. Regression with divided dataset (with 1 lag)

\begin{tabular}{|c|c|c|c|c|c|c|}
\hline & \multicolumn{3}{|l|}{ Non Trading Proxies } & \multicolumn{3}{|l|}{ Trading Proxies } \\
\hline & Amihud Illiquidity & Turnover Ratio & Spread & No. of shares & Log turnover & Turnover \\
\hline $\begin{array}{l}\text { Positive Change in } \\
\text { Gross Sales }\end{array}$ & $0.365 * * *$ & $-0.00169 * * *$ & $4 \mathrm{E}-06 * * *$ & $61987.0 * * *$ & $4.22 \mathrm{E}-04 * * *$ & $3.95 * * *$ \\
\hline$t$-statistic & -5.1 & $(-4.32)$ & -3.68 & -2.83 & -6.098 & -5.51 \\
\hline$R$-square & 0.104 & 0.08 & 0.05 & 0.03 & 0.148 & 0.124 \\
\hline $\begin{array}{l}\text { Negative Change } \\
\text { in Gross Sales }\end{array}$ & $-0.228 * * *$ & $0.001068 * * *$ & $-7.80 \mathrm{E}-07$ & -42604.7 & $-0.0003 * * *$ & $-2.792 * * *$ \\
\hline$t$-statistic & $(-4.15)$ & -3.78 & $(-0.851)$ & $(-2.21)$ & $(-4.45)$ & $(-4.83)$ \\
\hline$R$-square & 0.08 & 0.06 & 0.01 & 0.019 & 0.084 & 0.103 \\
\hline $\begin{array}{l}\text { Positive Change in } \\
\text { Gross Purchases }\end{array}$ & $0.221 * * *$ & $-0.00281 * * *$ & $2.7 \mathrm{E}-06^{* *}$ & $81584 * * *$ & $0.0004 * * *$ & $4.85 * * *$ \\
\hline$t$-statistic & -3.11 & $(-4.95)$ & -2.35 & -3.43 & -6.81 & -6.85 \\
\hline$R$-square & 0.04 & 0.103 & 0.01 & 0.04 & 0.18 & 0.188 \\
\hline $\begin{array}{l}\text { Negative Change } \\
\text { in Gross Purchases }\end{array}$ & $-0.162 * * *$ & $0.00101 * * *$ & $-8.37 \mathrm{E}-05$ & $-54440 * * *$ & $-0.0003 * * *$ & $-3.28 * * *$ \\
\hline$t$-statistic & $(-2.41)$ & -3.33 & $(-0.83)$ & $(-2.70)$ & $(-5.28)$ & $(-5.08)$ \\
\hline$R$-square & 0.02 & 0.05 & 0.01 & 0.02 & 0.12 & 0.103 \\
\hline
\end{tabular}

Note. $* * *$ Significant at $99 \%, * *$ Significant at $95 \%, *$ Significant at $90 \%$.

The FII flows of the week tend influence the future liquidity in the following week in Indian stock market. A $1 \%$ change in the gross purchases in the current week will result in .10\% decrease in the liquidity of the following week, whereas a $1 \%$ change in sales results in .12\% similar change. Both the FII purchases and sales had a positive impact on the spread inferring higher the FII flows: the higher the spread, the lower the liquidity. The estimates are statistically significant@99\% confidence level.

The turnover ratio has been computed as the ratio of rupee turnover to the market capitalization.Higher FII flows result in lower turnover ratios. The net FII also has a statistically significant negative impact on the illiquidity. $1 \%$ change in the Net FII results in $0.13 \%$ positive change in the future liquidity.

\subsubsection{Impact of Positive and Negative Changes}

The average weekly flows were highly volatile and substantially different from that of average daily changes in the week - the former represent average of aggregate purchases in the week, and the later represent the average of daily changes in the purchases. Granger tests results revealed that this average daily change within a week, granger causes the market liquidity. To further investigate this impact, the dataset was divided into two parts positive changes indicating the weeks where the FII purchases and sales increased vs. weeks that experienced a decline and negative values. The regression equations were independently estimated and the results are summarized in Tables 8.The results further confirm the primary finding that positive changes in Gross Sales and Purchases (i.e. an increase in the values on a weekly basis) significantly reduces the market's future liquidity, whereas a decrease in the FII trading activity increases the market liquidity. The decrease in the future liquidity from positive changes both in purchases and sales is higher compared to the impact of negative changes on increase in market liquidity. Further, positive FII changes also resulted in increase in rupee turn over, volume traded and log turnover values inferring strong interdependencies of the FII flows and trading activity in the Indian Stock Market.

\subsubsection{Results of Multiple Regression Analysis}

The Amihud ratio captures price impact while spread indicates bid-ask spread. Among these two liquidity proxies, FII flows had greater impact on Amihud liquidity.Turnover ratio and volume traded are the key variables that reflect the level of trading activity and influence the market liquidity in general. To validate the impact of FII flows, these variables have been added as control variables along with Amihud Illiquidity ratio as the dependent 
variable.

The results are summarized in Tables 9.1, 9.2 and 9.3. It was observed that despite the obvious impact of the turnover and the volume traded on market liquidity, the impact of FIIs is still found to be statistically significant (a) $99 \%$ confidence level. R square improved substantially with the addition of control variables andthe FII purchases, sales and net investments reconfirms negative impact on future liquidity of the market.

Table 9.1. Impact of gross purchases on amihud illiquidity

\begin{tabular}{llll}
\hline Amihud Illiquidity is the dependent variable & Model 1 & Model 2 & Model 3 \\
\hline Gross Purchases & $1.00 \mathrm{E}-03^{* * *}$ & $8.50 \mathrm{E}-04^{* * *}$ & $6.72 \mathrm{E}-04^{* * *}$ \\
t-stat & -11.78 & -9.53 & -6.31 \\
No. of shares traded & $1.02 \mathrm{E}-09$ & & $4.35 \mathrm{E}-09^{* *}$ \\
t-stat & -0.717 & & -2.8 \\
Turnover ratio & & $-3.58 \mathrm{E}-01 * * *$ & $-4.81 \mathrm{E}-01^{* * *}$ \\
t-stat & & $(-4.01)$ & $(-4.86)$ \\
R squared & 0.294 & 0.319 & 0.33 \\
\hline
\end{tabular}

Note. $* * *$ Significant at $99 \%, * *$ Significant at $95 \%, *$ Significant at $90 \%$.

Table 9.2. Impact of gross sales on amihud illiquidity

\begin{tabular}{llll}
\hline \multicolumn{1}{c}{ Amihud Illiquidity is the dependent variable } & Model 1 & Model 2 & Model 3 \\
\hline Gross Sales & $1.21 \mathrm{E}-03 * * *$ & $1.09 \mathrm{E}-03 * * *$ & $1.00 \mathrm{E}-03 * * *$ \\
t-stat & -11.78 & -12.75 & -9.89 \\
No. of shares traded & $3.57 \mathrm{E}-10$ & $-2.32 \mathrm{E}-09$ \\
t-stat & -0.273 & $-2.38 \mathrm{E}-01 * * *$ & $-3.02 \mathrm{E}-01 * *$ \\
Turnover ratio & & $(-2.83)$ & $(-3.26)$ \\
t-stat & & 0.403 & 0.406 \\
\hline R squared & 0.392 & &
\end{tabular}

Note. $* * *$ Significant at $99 \%, * *$ Significant at $95 \%$, * Significant at $90 \%$.

Table 9.3. Impact of net investment on amihud illiquidity

\begin{tabular}{llll}
\hline Amihud Illiquidity is the dependent variable & Model 1 & Model 2 & Model 3 \\
\hline Net Investment & $-1.57 \mathrm{E}-03 * * *$ & $-1.41 \mathrm{E}-03 * * *$ & $-1.65 \mathrm{E}-03 * * *$ \\
t-stat & $(-5.66)$ & $(-5.42)$ & $(-6.84)$ \\
No. of shares traded & $8.97 \mathrm{E}-09 * * *$ & $1.09 \mathrm{E}-08$ \\
t-stat & -6.16 & -8.58 \\
Turnover ratio & & $-8.02 \mathrm{E}-01 * * *$ & $-8.89 \mathrm{E}-01 * *$ \\
t-stat & & $(-9.82)$ & $(-11.68)$ \\
R squared & 0.126 & 0.225 & 0.34 \\
\hline
\end{tabular}

Note. $* * *$ Significant at $99 \%, * *$ Significant at $95 \%, *$ Significant at $90 \%$.

\section{Conclusion}

Globalisation and participation of foreign investors is expected to foster stock market development. This paper provides empirical assessment of this claim using alternative liquidity measures. FIIs and the portfolio flows have certainly contributed to the growth of stock market activity in India. Market capitalisation, volume and value traded grew significantly along with FII flows.

The results indicate that the foreign institutional trading significantly influences the market liquidity in a negative direction. An increase in the Gross Sales leads to an increase in the spread and the Illiquidity as measured by the Amihud illiquidity ratio and hence a decrease in future market liquidity. Similarly, an increase in Gross Purchases significantly reduces the future market liquidity. This is in direct agreement with the fact that the spread and the illiquidity rose by 10\% during 2002-2009, while the Gross Purchases and Gross Sales witnessed a growth of $39.2 \%$ and $37.9 \%$ respectively in the same period. The Net Investment has a significant positive impact on the future market liquidity. It is clear that positive Net Investment drives up the future market 
liquidity, whereas a withdrawal would cause a liquidity crunch in the market.

\section{References}

Agarwal, P. (2007, November) Institutional ownership and stock liquidity. Cornell University Working Paper. Retrieved from http://papers.ssrn.com/sol3/papers.cfm?abstract_id=1029395

Agarwal, S., Faircloth, L. C., \& Rhee, S. G. (2009). Why do foreign investors underperform domestic investors in trading activities? Evidence from Indonesia. Journal of Financial Markets, 12(1), 32-53. http://dx.doi.org/10.1016/j.finmar.2008.04.001

Aguiar, M., \& Gopinath, G. (2005). Fire-sale foreign direct investment and liquidity crises. The Review of Economics and Statistics, 87(3), 439. http://dx.doi.org/10.1162/0034653054638319

Amihud, Y. (2002). Illiquidity and stock returns: Cross-section and time-series effects. Journal of Financial Markets, 5(1), 31-56. http://dx.doi.org/10.1016/S1386-4181(01)00024-6

Amihud, Y., Mendelson, H., \& Lauterbach, B. (1997, October). Market microstructure and securities values: Evidence from the tel aviv stock exchange. NYU Stern Working Paper. Retrieved from http://archive.nyu.edu/bitstream/2451/26846/2/wpa98004.pdf

Bailey, W., \& Jagtiani, J. (1994). Foreign ownership restrictions and stock prices in the Thai capital market. Journal of Financial Economics, 36(1), 57-87. http://dx.doi.org/10.1016/0304-405X(94)90030-2

Bekaert, G., \& Harvey, C. R. (2000). Foreign speculators and emerging equity markets. Journal of Finance, 55(2), 565-614.

Bekaert, G., Harvey, C. R., \& Lundblad, C. (2001). Emerging equity markets and economic development. Journal of Development Economics, 66(2), 465-504. http://dx.doi.org/10.1016/S0304-3878(01)00171-7

Bekaert, G., Harvey, C. R., \& Lundblad, C. (2002). Dating the integration of world equity markets. Journal of Financial Economics, 65(2), 203-247. http://dx.doi.org/10.1016/S0304-405X(02)00139-3

Bekaert, G., Harvey, C. R., \& Lundblad, R. L. (2007). Liquidity and expected returns: Lessons from emerging markets. Review of Financial Studies, 20(6), 1783-1831. http://dx.doi.org/10.1093/rfs/hhm030

Berkman, H., \& Eleswarapu, V. R. (1998). Short-term traders and liquidity: a test using bombay stock exchange data. Journal of Financial Economics, 47(3), 339-355. http://dx.doi.org/10.1016/S0304-405X(97)00048-2

Biais, B. (1993). Price formation and equilibrium liquidity in fragmented and centralized markets. The Journal of Finance, 48(1), 157-185. http://dx.doi.org/10.1111/j.1540-6261.1993.tb04705.x

Bortolotti, B., Jong, F. D., Nicodano, G., \& Schindele, I. (2007). Privatization and stock market liquidity. Journal of Banking \& Finance, 31(2), 297-316. http://dx.doi.org/10.1016/j.jbankfin.2006.04.008

Brennan, M. J., Chordia, T., \& Subrahmanyam, A. (1998). Alternative factor specifications, security characteristics, and the cross-section of expected stock returns. Journal of Financial Economics, 49(3), 345-373. http://dx.doi.org/10.1016/S0304-405X(98)00028-2

Chakrabarti, A. (2001). The determinants of foreign direct investments: Sensitivity analyses of cross-country regressions. Kyklos, 54(1), 89-114. http://dx.doi.org/10.1111/1467-6435.00142

Chakraborty, T. (2007). Foreign institutional investment flows and Indian stock market returns: A cause and effect relationship study. Indian Accounting Review, 11(1), 35-48.

Chan, K., Covrig, V., \& Ng, L. (2005). What determines the domestic bias and foreign bias, Evidence from mutual fund equity allocations worldwide? The Journal of Finance, 60(3), 1495-1534. http://dx.doi.org/10.1111/j.1540-6261.2005.768_1.x

Choe, H., Kho, B. C., \& Stulz, R. M. (1999). Do foreign investors destabilize stock markets? The Korean experience in 1997. Journal of Financial Economics, 54(2), 227-264. http://dx.doi.org/10.1016/S0304-405X(99)00037-9

Chordia, T., Roll, R., \& Subrahmanyam, A. (2001). Market liquidity and trading activity. The Journal of Finance, 56(2), 501-530. http://dx.doi.org/10.1111/0022-1082.00335

Corwin, S. A., \& Schultz, P. (2012). A simple way to estimate bid-ask spreads from daily high and low prices. The Journal of Finance, 67(2), 719-759. http://dx.doi.org/10.1111/j.1540-6261.2012.01729.x

Covrig, V., Lau, S. T., \& Ng, L. (2006). Do domestic and foreign fund managers have similar preferences for stock characteristics? A cross-country analysis. Journal of International Business Studies, 37(3), 407-429. 
http://dx.doi.org/10.1057/palgrave.jibs.8400195

Dahlquist, M., \& Robertsson, G. (2001). Direct foreign ownership, institutional investors, and firm $\begin{array}{lllll}\text { characteristics. Journal of } & \text { Financial }\end{array}$ http://dx.doi.org/10.1016/S0304-405X(00)00092-1

Datar, V. T., Naik, N. Y., \& Radcliffe, R. (1998). Liquidity and stock returns: An alternative test. Journal of Financial Markets, 1(2), 203-219. http://dx.doi.org/10.1016/S1386-4181(97)00004-9

Doidge, C., Karolyi, G. A., \& Stulz, R. M. (2004). Why are foreign firms listed in the U.S. worth more? Journal of Financial Economics, 71(2), 205-238. http://dx.doi.org/10.1016/S0304-405X(03)00183-1

Domowitz, I., Glen, J., \& Madhavan, A. (2001). Liquidity, volatility, and equity trading costs across countries and over time. International Finance, 4(2), 221-255. http://dx.doi.org/10.1111/1468-2362.00072

Ferreira, M. A., \& Matos, P. (2008). The colors of investors' money: The role of institutional investors around the world. Journal of Financial Economics, 88(3), 499-533. http://dx.doi.org/10.1016/j.jfineco.2007.07.003

Gabaix, X., Gopikrishnan, P., Plerou, V., \& Stanley, H. E. (2006). Institutional investors and stock market volatility. Quarterly Journal of Economics, 121(2), 461-504. http://dx.doi.org/10.1162/qjec.2006.121.2.461

Glosten, L. R., \& Milgrom, P. R. (1985). Bid, ask and transaction prices in a specialist market with heterogeneously informed traders. Journal of Financial Economics, 14(1), 71-100. http://dx.doi.org/10.1016/0304-405X(85)90044-3

Grinblatt, M., \& Keloharju, M. (2000). The investment behavior and performance of various investor types: a study of Finland's unique data set. Journal of Financial Economics, 55(1), 43-67. http://dx.doi.org/10.1016/S0304-405X(99)00044-6

Heflin, F., \& Shaw, K. W. (2000). Block holder ownership and market liquidity. The Journal of Financial and Quantitative Analysis, 35(4), 621-633. http://dx.doi.org/10.2307/2676258

Henry, P. B. (2000). Do stock market liberalization cause investment booms? Journal of Financial Economics, 58(1-2), 301-334. http://dx.doi.org/10.1016/S0304-405X(00)00073-8

Jun, S. G., Marathe, A., \& Shawky, H. A. (2003). Liquidity and stock returns in emerging equity markets. Emerging Markets Review, 4(1), 1-24. http://dx.doi.org/10.1016/S1566-0141(02)00060-2

Kamesaka, A., Nofsinger, J. R., \& Kawakita, H. (2003). Investment patterns and performance of investor groups in Japan. Pacific-Basin Finance Journal, 11(1), 1-22. http://dx.doi.org/10.1016/S0927-538X(02)00095-1

Khanna, T., \& Palepu, K. (1999, February). Emerging market business groups, foreign investors, and corporate governance. NBER Working Paper, No.6955. Retrieved from http://www.nber.org/papers/w6955

Kyle, A. P. (1985). Continuous auctions and insider trading. Econometrica, 53(6), 1315-1336. http://dx.doi.org/10.2307/1913210

Lesmond, D. A. (2005). Liquidity of emerging markets. Journal of Financial Economics, 77(2), 411-452. http://dx.doi.org/10.1016/j.jfineco.2004.01.005

Lesmond, D. A., Ogden, J. P., \& Trzcinka, C. A. (1999). A new estimate of transaction costs. Review of Financial Studies, 12(5), 1113-1141. http://dx.doi.org/10.1093/rfs/12.5.1113

Levine, R., \& Zervos, S. (1998). Capital control liberalization and stock market development. World Development, 26(7), 1169-1183. http://dx.doi.org/10.1016/S0305-750X(98)00046-1

Mitra, D., \& Golderm, P. N. (2002). Whose culture matters? Near-market knowledge and its impact on foreign market entry timing. Journal of Marketing Research, 39(3), 350-365. http://dx.doi.org/10.1509/jmkr.39.3.350.19112

Mukherjee, P., Bose, S., \& Condoo, D. (2002). Foreign institutional investment in the Indian equity market: An analysis of daily flows during January 1999-May 2002. ICRA Bulletin Money \& Finance, 21-51. Retrieved from http://www.icra.in/Files/MoneyFinance/aprsep2002equity.pdf

Pritsker, M. (2005, September). Large investors, implications for equilibrium asset returns, shock absorption, and liquidity. FEDS Working Papers, N0.36. Retrieved from http://www.federalreserve.gov/pubs/feds/2005/200536/200536pap.pdf

Ramirez, M. D. (2006). Is foreign direct investment beneficial for Mexico? An empirical analysis, 1960-2001. World Development, 34(5), 802-817. http://dx.doi.org/10.1016/j.worlddev.2006.01.001 
Ross, L., \& Schmukler, S. L. (2003, April). Migration, spillovers, and trade diversion: The impact of internationalization on domestic stock market liquidity. NBER Working Paper, No.9614. Retrieved from http://www.nber.org/papers/w9614.pdf?new_window=1

Rubin, A. (2007). Ownership level, ownership concentration and liquidity. Journal of Financial Markets, 10(3), 219-248. http://dx.doi.org/10.1016/j.finmar.2007.04.002

Sarin, A., Shastri, K. A., \& Shastri, K. (1999, November). Ownership structure and stock market liquidity. University of Pittsburgh Working Paper. Retrieved from http://papers.ssrn.com/sol3/papers.cfm?abstract_id=2652

Stulz, R. (1999, March). Globalization of equity markets and the cost of capital. NBER Working Paper, No. 7021. Retrieved from http://papers.ssrn.com/sol3/papers.cfm?abstract_id=153669

Stulz, R. M. (1999, August). International portfolio flows and security markets (pp. 257-293). Woodstock Conference on International Capital Flows NBER Conference Report Series. Chicago \& London: University of Chicago Press.

Torre, A. D. L., Gozzi, J. C., \& Schmukler, S. L. (2007). Stock market developments under globalization: Whither the gains from reforms? Journal of Banking \& Finance, 31(6), 1731-1754. http://dx.doi.org/10.1016/j.jbankfin.2006.11.008

Wang, J. (2007). Foreign equity trading and emerging market volatility: Evidence from Indonesia and Thailand. Journal of Development Economics, 84(2), 798-811. http://dx.doi.org/10.1016/j.jdeveco.2006.05.001

Wei, C. (2010, November). Do foreign institutions improve stock liquidity? University of Texas at Austin Working paper. Retrieved from https://webspace.utexas.edu/cw2932

\section{Notes}

Note 1. International Monetary Fund report. Issue 2011-05-26 \& Reserve bank of India: Foreign direct investment at the end of March-2010.

Note 2. Handbook of Statistics, SEBI 2010.

Note 3. As reported on the Bombay stock exchange (BSE).

Note 4. Table headers are abbreviated as: GP, GS, NI: Gross purchases, Gross sales and Net Investment. CGP, CGS, CNI: Weekly change in Gross purchases, Sales and Net Investment. LCGP, LCGS, LCNI: Log of changes in Purchases, sales and net investment.

\section{Copyrights}

Copyright for this article is retained by the author(s), with first publication rights granted to the journal.

This is an open-access article distributed under the terms and conditions of the Creative Commons Attribution license (http://creativecommons.org/licenses/by/3.0/). 